\title{
Contrasting centenaries: how Russia, Ukraine and Belarus marked
}

\section{October}

\author{
Francis King, University of East Anglia \\ Olena Palko, Birkbeck, University of London
}

The 'Great October Socialist Revolution' of 1917 was the foundational event for the USSR, continually invoked by the CPSU to justify the Soviet state and its political and economic order. Its anniversary on 7 November was the major public holiday in the Soviet Union, and up to 1990 was celebrated across the Union in thousands of official marches, meetings and ceremonies large and small.

After 1991, following the dissolution of both the Union and the party, the anniversary lost its raison d'être as a public holiday, not least because in several of the former Union republics, there had been no 'October revolution' - the Soviet system had been established by quite different means, at different times, often against serious local resistance. The fifteen successor states to the USSR needed to devise their own foundational stories, usually on the basis of national mythology. If 'October' played any kind of role in these stories, it was often a negative one.

For the most part, celebration of the anniversary across the former Soviet Union after 1991 became the exclusive preserve of the local communist parties, where these were allowed to exist openly. Over the years the day ceased to be a public holiday, and the state authorities generally simply ignored it. The hundredth anniversary in 2017 , however, could not be passed over in silence - it would have to be commemorated in some way. 
As the centenary of 'October' approached, academics and journalists in Western countries speculated about how the anniversary would be marked in Russia. Much of the discussion hinged around the political difficulties for the Russian authorities in taking any kind of unambiguous 'line' on the revolution. While aspects of the Soviet past can easily be woven into a widely acceptable grand patriotic narrative of Russian statehood from the ninth century to the present day - for example, Soviet victory in the 'Great Patriotic War' or achievements in the Space Race - the revolution itself cannot. Russia's rulers can find little cheer in the liberal and democratic impulses of February 1917, the insurrectionary élan of October, the background of state collapse and military defeat, or the fratricidal civil war which ensued. Nor is there any consensus in Russian society - on such basic questions as whether October 'expressed the will of the people' at the time, public opinion seems to be split down the middle. ${ }^{1}$

Wisely, the Russian authorities chose to avoid giving any official interpretation of the events of 1917, and, to the extent that they tried to use the anniversary for current political purposes at all, pushed instead the theme of 'reconciliation'. ${ }^{2}$ This relative political disinterestedness almost certainly had a beneficial impact on the quality of the officiallysponsored events. At the end of 2016, Vladimir Putin issued an instruction 'recommending' that the Russian Historical Society convene an organising committee to plan events to mark the occasion and that other public bodies, educational institutions, and local authorities participate. ${ }^{3}$ The result was an impressive and diverse array of exhibitions, international

\footnotetext{
${ }^{1}$ VTsIOM survey, 3-4 December 2016. Results reported on https://wciom.ru/index.php?id=236\&uid=116446 [Accessed 21.01.2018].

${ }^{2}$ For an account of this, see Sheila Fitzpatrick, 'Celebrating (or Not) the Russian Revolution' in Journal of Contemporary History, Vol. 52/4, October 2017, pp 816-831, esp. 827-829.

${ }^{3}$ For the instruction, see http://rushistory.org/images/documents/0001201612200017.pdf [Accessed 21.01.2018].
} 
conferences, round tables, publications, performances, concerts and so on across Russia and abroad. $^{4}$

Not one of these events was a 'celebration' of the revolution. Celebration was left to political organisations, above all the Communist Party of the Russian Federation (KPRF). The KPRF website carries detailed reports with photographs of the numerous central and local events it organised. Almost all of them followed a template laid down long before the collapse of the USSR, when the CPSU was still the ruling party: marches with banners and flags, flowers laid at the base of Lenin monuments, and set-piece speeches by party leaders. In some places there were also indoor rallies with more speeches, presentations, folk ensembles or patriotic songs. Images of Lenin and Stalin featured prominently, and the design of the banners and backdrops was very much in the Late Soviet style. The nostalgic tone of these events was set by the party's list of official slogans, which included 'Lenin Stalin - Victory!', 'We are proud of the land of Soviets!', and, possibly rather tellingly, 'We need pensions and not handouts! 5 The most forward-looking celebratory event listed on the KPRF site took place in a village in Crimea, where the local party branch honoured the centenary by planting 50 trees in the main square. ${ }^{6}$

The centenary has led to a flurry of books and publications of varying quality, some academic, some aimed at a popular audience. One effort which stands out for the originality of its conception is The Empire Must Die, by the journalist Mikhail Zygar. He tells the story

\footnotetext{
${ }^{4}$ For the list of centrally-planned events, see http://rushistory.org/images/documents/plan100letrevolution.pdf, a supplementary list of regionallyplanned initiatives is on http://rushistory.org/images/documents/region-plan-revolution100.pdf . [Accessed 21.01.2018].

${ }^{5}$ The slogans were appended to the KPRF programme of central events to be held in Petersburg and Moscow, published on https://kprf.ru/announcements/113434.html. [Accessed 21.01.2018]

${ }^{6}$ The report, with pictures, can be seen on https://kprf.ru/party-live/regnews/170654.html. [Accessed 21.01.2018]
} 
of the revolution through the experiences of particular participants, basing his work on their diaries and memoirs, and the project has been accompanied by a website which presents these people's words in the format of present-day social media. The result is a resource - available in both Russian and English - which will be invaluable for anyone interested in understanding and comparing the mentalities of people at the time. ${ }^{7}$

Overall, the absence of any officially-sanctioned, semi-obligatory interpretation of the revolution in Russia has meant that the best of the commemorative output in Russia has been of high quality and very useful for anyone interested in the history. On the other hand, for those Russians not interested in the history, it has been very easy to ignore the centenary. As the historian Ivan Kurilla lamented in the newspaper Vedomosti last year, 'For the ordinary citizen of Russia, the centenary of the revolution is passing unnoticed' ${ }^{8}$ The authorities' inability to find a way to use it for current political purposes has meant that commemoration, celebration or even study of the revolution has been left to the academics and activists.

The position in Ukraine is quite different. If how to remember 1917 presents difficulties for the authorities in Russia, in Ukraine a particular interpretation of the events has come to play an essential part in its nation- and state-building. 2017 was widely celebrated as the centenary, not of the 'Russian', but of the Ukrainian Revolution. On 22 January 2016, the Day of Ukrainian Unity, ${ }^{9}$ President Petro Poroshenko decreed that commemoration of the Ukrainian Revolution of 1917-21 was to be a priority of state memory

\footnotetext{
${ }^{7}$ For details of the English translation of Zygar's book see https://www.littlebrown.co.uk/books/detail.page?isbn=9781610398312. The English-language version of the interactive website is on https://project1917.com. [Accessed 21.01.2018]

${ }^{8}$ Ivan Kurilla, 'Tikhiy yubiley Oktyabrya' in Vedomosti, 24 October 2017, online edition on https://www.vedomosti.ru/opinion/articles/2017/10/25/739251-yubilei-oktyabrya. [Accessed 21.01.2018]

${ }^{9}$ The day when an agreement between the Ukrainian People's Republic and the West Ukrainian People's Republic was signed in 1919 aimed at creating a unified Ukrainian state.
} 
politics over the next five years. ${ }^{10} \mathrm{He}$ emphasised a continuity between the struggle for Ukraine's independence and national unity (sobornist') in 1917-21 and the declaration of independence in 1991. In this interpretation, Ukraine's history of independence was interrupted by the 70-years-long Soviet era, brought about through Red Army military interventions in 1917-21 and subsequent occupation. ${ }^{11}$ A comprehensive commemorative programme for 2017 ensued, including an exhibition 'One Hundred Years of the Ukrainian Revolution. The State Regained' at the National Museum of the History of Ukraine; raising monuments to national unity and to the leader of the Ukrainian People's Republic (UNR) Symon Petliura, and launching a search project 'Sites of memory of the Ukrainian Revolution $1917-21^{\prime}$

A central part in organising and framing these commemorations was played by the Ukrainian Institute of National Memory (UINP). This is an official government body, whose task was defined by its first head Igor Iukhnovs'kyi in 2007 as 'developing measures aimed at consolidating and augmenting the state-building patriotism of the people of Ukraine'. ${ }^{12}$ UINP has contributed actively to the politicisation of history in Ukraine, particularly since the 'Maidan revolution' of 2014, when UINP was taken over by the historian and Ukrainian

\footnotetext{
${ }^{10}$ The Law of Ukraine no 17/2016 "Pro zakhody z vidznachennia 100-richchia podii Ukrains'koi revoliutsii 1917-1921 rokiv" from 22 January 2016: http://www.president.gov.ua/documents/17201619736 [Accessed 17.01.2018]

${ }^{11}$ The view that 1991 marked the renewal rather than the first declaration of Ukraine's statehood has been advanced by UINP head Volodymyr Viatrovych.

https://www.unian.ua/politics/2334317-vyatrovich-nazvav-period-perebuvannya-ukrajini-u-skladisrsr-okupatsieyu.html [Accessed 17.01.2018]

${ }^{12}$ See Igor Yukhnovsky, 'Ob ideologii i politike Ukrainskogo instituta natsional'noy pamyati' in $Z N, U A, 26$ October 2007, on https://zn.ua/SOCIETY/ob ideologii i politike ukrainskogo instituta natsionalnoy pamyati.html
} [Accessed 24.01.2018] 
nationalist activist Volodymyr Viatrovych. The initiative for the so-called 'decommunisation' laws, adopted in 2015, came from Viatrovych's UINP.

This new official narrative of 1917-21 in Ukraine marks a complete break not only with Soviet historiography, but also with the way history had previously been written in post1991 Ukraine. 1917 in Ukrainian history should no longer be associated with the October Revolution. Neither should it be discussed as the beginning of 'the revolution in Ukraine' which suggests that the events in Ukraine were simply a regional version of the revolution in Russia - or as 'the civil war'. Between the Ukrainian parties, so the argument goes, there were no major conflicts during the Russian civil war. In this way, the Bolshevik Red Army, the White monarchist movements, and even the anarchist Makhno movement are excluded from the narrative of Ukrainian statehood. ${ }^{13}$ However, Viatrovych presents this as 'not rewriting history, but simply writing it in the first person' ${ }^{14}$

This new historical narrative of 1917-21 fits seamlessly with the process of decommunisation, which intensified in 2014. The 2015 decommunisation legislation seeks to undo the historical legacy of the Soviet era in Ukraine by banning any favourable public appraisals of the Soviet past or any attempt to excuse the 'criminal nature of the communist totalitarian regime of 1917-1991 in Ukraine'. ${ }^{15}$ These laws leave no room for rethinking the Soviet heritage in Ukraine. Neither do they allow an objective study of the 1917-21 events. The decommunisation laws and the activities of the UINP in particular cement an 'either...

\footnotetext{
${ }^{13}$ The Interview with Stanislav Kul'chyts'kyi on how to commemorate the centenary of the Ukrainian revolution: https://www.radiosvoboda.org/a/28229487.html [Accessed 17.01.2018]

14 "The Centenary of the Ukrainian revolution: How to honour the UNR?": http://memory.gov.ua/news/storichchya-ukrainskoi-revolyutsii-yak-vshanovuvatimut-unr [Accessed 17.01.2018]

${ }^{15}$ Law on the Condemnation of the Communist and National Socialist (Nazi) Regimes, and Prohibition of Propaganda of Their Symbols, 9 April 2015. English translation:
} http://www.venice.coe.int/webforms/documents/default.aspx?pdffile=CDL-REF\%282015\%29045-e [Accessed 17.01.2018] 
or' paradigm in Ukrainian historiography and public discourse, according to which there were only two contending parties in Ukraine during the revolutionary years: fighters for the national cause on the one hand, and the Russian-led occupiers, primarily the Bolsheviks, on the other. The October Revolution, according to the Director of the Museum of the Ukrainian Revolution Oleksandr Kucheruk, was merely a phase in a process of reorganising the Russian Empire. ${ }^{16}$

While the official narrative glorifies the national liberation aspect of 1917-21, Ukraine's major left-wing political forces continue to assert that it was the Bolshevik Party which emancipated the 'oppressed peoples' of the former empire from tsarist autocracy and foreign interventionists; established the first independent workers' and peasants' state Soviet Ukraine, and gathered ethnic Ukrainian lands under its rule. ${ }^{17}$ The Communist Party of Ukraine (KPU) used the centenary of October to remind its followers of the grand achievements of the Soviet era, fraternity between the Soviet republics, wise leadership of the CPSU and prosperity of the people across the Soviet Union, contrasting this picture with the corruption of Ukraine's present government and its complete dependency on foreign capital.

The KPU (along with two other marginal communist parties) has officially been banned in Ukraine in line with the decommunisation legislation. ${ }^{18}$ Nonetheless, it managed to hold some centenary events, most notably a conference on 'The Great October and the Future of Ukraine' in Kyiv on 20 October 2017. The keynotes were the unchallenged KPU leader Petro Symonenko and two celebrated historians and members of the Academy of Sciences

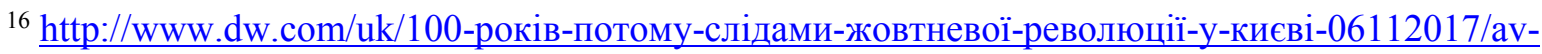
$\underline{41249304}$ [Accessed 17.01.2018]

${ }^{17}$ The Address of Petro Symonenko: https://kpu.ua/ru/88342/zvernennja_pershogo_sekretarja_tsk_kpu_petra_symonenka_z_nagody_100ri chchja_velykoji_zhovtnevoji_sotsialistychnoji_revoljutsiji [Accessed 17.01.2018]

${ }^{18}$ On the ban of the KPU: https://www.unian.ua/politics/1245910-vischiy-adminsud-pidtverdivzakonnist-zaboroni-kpu-minyust.html [Accessed 17.01.2018]
} 
Petro Tolochko, and Valerii Soldatenko - a KPU member since 1969 who had himself been in charge of UINP from 2010 until Viatrovych took over in March 2014. ${ }^{19}$ At another KPU gathering in Kyiv on 6 November, Soldatenko was awarded the KPU's 'Lenin Prize' for his four-volume monograph 'Ukraina v revoliutsiinu dobu' [Ukraine in the Revolutionary Era]. ${ }^{20}$

Local commemorations, organised by the KPU and other left-wing parties, were necessarily low-key. Here and there, where the decommunisation laws had not yet been implemented, there were loose processions through streets named after Soviet heroes and ceremonies next to Soviet memorials. The KPU website only reported two cases where flowers were laid at the foot of statues of Lenin - in Ochakiv (Mykolaiv region) and Krasnoarmeisk (Donets'k region, now the territory of the self-proclaimed Donets'k People's Republic). ${ }^{21}$ Most ceremonies took place in the local party cells, with thematic meetings and debates, presentations to party activists, and amateur performances of revolutionary folklore.

On 6 November Symonenko addressed his comrades with a long speech, in which he harshly criticised the new official narrative of the 1917 events in Ukraine. He urged the Ukrainian president to take a closer look at some of the Ukrainian heroes of 1917-21, in particular the UNR leaders Volodymyr Vynnychenko and Mykhailo Hrushevs'kyi, who later came to recognise the Bolshevik Party and were keen to contribute to building Soviet

\footnotetext{
${ }^{19}$ The conference proceedings: https://www.kpu.ua/ru/88743/velykyj_oktjabr_y_buduschee_ukrayny sbornyk_materyalov_sostojavs hejsja_20_oktjabrja_2017 goda_v kyeve nauchnopraktycheskoj_konferentsyy posvjaschennoj_1001 etyju_velykoj_oktjabrskoj_sotsyalystycheskoj_revoljutsyy [Accessed 17.01.2018]

${ }^{20}$ The report on the celebratory session in Kyiv:

https://www.kpu.ua/ru/88343/v_kyeve_sostojalos_torzhestvennoe_sobranye_posvjaschennoe_100lety ju_velykoj_oktjabrskoj_sotsyalystycheskoj_revoljutsyy [Accessed 17.01.2018]

${ }^{21}$ Regional reports on the commemoration of the October revolution: https://kpu.ua/ru/archive/201711-06 [Accessed 17.01.2018]
} 
Ukraine. ${ }^{22}$ Overall, though, little has changed in the way the KPU presents 1917: the October Revolution was the greatest achievement of the (all-Russia) Bolsheviks, who embraced the toilers' demands in the peripheries and established Soviet power across the former empire.

Both these dominant perspectives disregard Ukraine's indigenous socialist and communist traditions. Nonetheless, some people did try to use the centenary of the October Revolution to focus on the legacy of Ukrainian 'national communism', an ideological standpoint or orientation shared by a number of left movements and parties in 1918-1925, whose aim was to find a national way to socialism without slavishly imitating patterns set in Russia. National communism is not new for Ukrainian historiography. The previous UINP head Soldatenko had often been accused of being a 'national communist' when he argued for a comprehensive approach to national memory, incorporating those often inconvenient experiences such as Ukrainian communism. ${ }^{23}$

Examining the role of national communists and the peculiarities of establishing the Soviet regime in Ukraine provides a more nuanced account of the events of 1917-21. For instance, an online platform Vpered [Forward] publishes little known documents and contributions of Ukrainian communists, as well as Ukrainian translations of Russian sources concerning Ukraine. Another blog Proletar Ukrainy [Proletarian of Ukraine] discovers and publishes sources on establishing Soviet Power in Ukraine, offering a local perspective on the events in question. In November 2017 a number of publications and blog posts were featured

\footnotetext{
${ }^{22}$ The speech of Symonenko:

https://kpu.ua/ru/88344/oktjabr_uchyt_vdohnovljaet_zovet_k_obnovlennomu sotsyalyzmu_doklad_p ervogo_sekretarja_tsk_kpu_pnsymonenko_na torzhestvennom_sobranyy posvjaschennom_100letyju _velykoj_oktjabrskoj_sotsyalystycheskoj_revoljutsyy_6_nojabrja_2017_goda [Accessed 17.01.2018]

${ }^{23}$ The interview with Valerii Soldatenko from 23.03.2011 http://www.istpravda.com.ua/articles/2011/03/23/32857/ [Accessed 17.01.2018]
} 
dedicated to examining the events of October 1917 in Ukraine. ${ }^{24}$ The main author of Proletar Ukrainy, Andrii Zdorov, argues that there was a 'Ukrainian October', and that Soviet power in Ukraine resulted from a grassroots mass movement championed by Ukrainian Bolsheviks (e.g., Georgii Lapchyns'kyi and Vasyl' Shakhrai). ${ }^{25}$ Although Zdorov's claims could easily be challenged by extending the pool of primary sources, ${ }^{26}$ such accounts offer a necessary alternative to the long outdated mainstream left narrative. They show that there is still a need to re-evaluate early Soviet history in Ukraine, a task effectively precluded by the decommunisation initiatives of UINP and Ukraine's present government.

The position in Belarus is quite different in almost every respect. It claims to be a 'social' (but not a 'socialist') state, ${ }^{27}$ and most of the Soviet-era public iconography, monuments and place names has been retained. Since coming to power in 1994 Aleksandr Lukashenko has sought to rule by conserving many of the political and economic structures and practices inherited from the Soviet past, and using them in support of his version of Belarusian statehood. The centenary of October, still a public holiday in Belarus, was also coopted. Lukashenko's official centenary greetings noted that Soviet-era 'socio-economic principles' had 'underpinned the development of the industrial, scientific, agricultural

\footnotetext{
${ }^{24}$ For instance: https://vpered.wordpress.com/2017/11/ ; https://proletar-ukr.blogspot.co.uk/2017/11/ [Accessed 17.01.2018]

${ }^{25}$ Andrii Zdorov, Ukrains 'kyi Zhovten'. Bil'shovyts'ka revoliutsiia v Ukraiini: sotsial'no-politychnyi aspect (lystopad 1917-liutyi 1918) (Odesa, 2007) (Available online: https://vpered.wordpress.com/2011/11/07/zdorov-der-ukrainisch-oktober/)

${ }^{26}$ Review by Hennadii Efimenko:

http://uamoderna.com/images/archiv/14/14_UM_14_Dyskusii_Jefimenko.pdf [Accessed 17.01.2018]

${ }^{27}$ This formulation is found in article 1 of the 1994 Constitution; see e.g. http://pravo.by/pravovayainformatsiya/normativnye-dokumenty/konstitutsiya-respubliki-belarus/
} 
potential of the Belorussian state today', ${ }^{28}$ a claim which is historically accurate but largely meaningless.

State input into the actual celebrations was minimal - in Minsk, for example, a few soldiers lay flowers at the Lenin statue on Independence Square and a small military band provided the music, but other than that, as in Russia, the business of mobilising for the ceremony was left to the main communist party (KPB). The result was a small, low-key event attended by 'dozens' of people, as Minsk television reported. ${ }^{29}$ Unlike in Russia, where the KPRF is at least nominally in opposition to Putin's government, the KPB is wholly aligned with the Lukashenko regime. As the KPB Central Committee statement for the centenary enthused: 'transformed through the prism of time, the social postulates of Great October find expression in the present-day Belorussian model of development. It is no accident that 7 November is a holiday in our country'. ${ }^{30}$

Vyacheslav Danilovich, the director of the Belarusian Academy of Sciences' Institute of History, interviewed just before the anniversary for the official paper Zviazda, was altogether more ambivalent about the role of October in Russian and Belarusian history. On the one hand, revolutions are an 'abnormal phenomenon in the development of society', but on the other hand, it was thanks to Lenin's line on self-determination that the Belorussian SSR was proclaimed and 'Belarusian national statehood was realised in practice'. ${ }^{31}$

\footnotetext{
${ }^{28} \mathrm{See}$ http://president.gov.by/ru/news_ru/view/pozdravlenie-so-100-letnim-jubileem-oktjabrskojrevoljutsii-17408/

${ }^{29}$ For coverage of the ceremony in Minsk, see e.g. http://www.ctv.by/belarus-otmechaet-100-letieoktyabrskoy-revolyucii [Accessed 24.01.2018]

${ }^{30} \mathrm{See}$ http://comparty.by/xv-plenum-ck-kpb-obrashchenie-kommunisticheskoy-partii-belarusi-k-100letiyu-velikoy-oktyabrskoy [Accessed 20.01.2018]

${ }^{31}$ Interview with Vladislav Lukashevich, 'Blagodarya Oktyabr'skoy revolyutsii poyavilas' nezavisimaya Belarus", Zviazda, 4 November 2017, on http://zviazda.by/ru/news/20171104/1509781173-blagodarya-oktyabrskoy-revolyucii-poyavilasnezavisimaya-belarus [Accessed 24.01.2018]
} 
As in Russia, this official ambivalence about October has meant a relatively free discussion of its significance has been possible in Belarus. On 3 November, the very official paper Sovetskaya Belorussiya published a round-table discussion between Danilovich, deputy KPB leader Georgiy Atamanov, and two sharp critics of Bolshevism, the political scientist Valeriy Karbalevich and Vadim Mozheyko from the Liberal Club in Minsk. While Danilovich repeated the claim that October led to Belarusian statehood and Atamanov aired well-rehearsed pro-Bolshevik arguments, Karbalevich argued that the Soviet period had been a detour from humanity's common path of development. Mozheyko reminded his interlocutors that for all this talk about statehood, Lenin's government had twice ceded Belarusian territory - to Germany in 1918 and to Poland in 1921 - without consulting the locals. $^{32}$

Belarus is now the only former Union republic which has retained the 7 November holiday with its previous designation, albeit largely emptied of its former meaning. Up to a few weeks before the centenary, Kyrgyzstan, the impoverished but pluralistic Central Asian republic, had also kept the 7 November holiday as the anniversary of October. But on 26 October 2017 the Kyrgyz President, Almazbek Atambaev, issued a decree redesignating 7 and 8 November as 'Days of History and Remembering Ancestors'. Referring favourably to the 'de-ideologisation of historical science', Atambaev's decree identified three main events worthy of commemoration on those days: 'the ordinary anniversary of the National Liberation Uprising of 1916 , the $100^{\text {th }}$ anniversary of the Great October Socialist Revolution and the $80^{\text {th }}$ anniversary of the political repressions'. ${ }^{33}$

\footnotetext{
32 'Oktyabr' 17-go: vzglyad cherez stoletie', in Sovetskaya Belorussiya, 3 November 2017, on https://www.sb.by/articles/oktyabr-17-go-vzglyad-cherez-stoletie.html [Accessed 24.01.2018]

${ }^{33}$ For the text of the decree see http://www.president.kg/ru/novosti/10760 prezident_almazbek_atambaev_podpisal_ukaz_ob_ustano vlenii_dney_istorii_i pamyati_predkov/ [Accessed 25.01.2018]
} 
What is to be done with October? Across the former USSR political leaders have been grappling with this question. Whether any of them have yet found a viable answer remains to be seen. 